\title{
EFFECT OF LAND USE CHANGE ON LAKE WATER QUALITY IN DIFFERENT BUFFER ZONES
}

\author{
SU, Z.H. ${ }^{1,2,3}-$ LIN, C. ${ }^{2,3^{*}}-$ MA, R.H. ${ }^{2}-$ LUO, J.H. ${ }^{2}-$ LIANG, Q.O. ${ }^{1 *}$ \\ ${ }^{1}$ College of Geography and Environmental Sciences \\ Zhejiang Normal University \\ 688 Yingbin road, Jinhua 321004, P.R.China \\ ${ }^{2}$ State Key Laboratory of Lake Science and Environment \\ Nanjing Institute of Geography and Limnology \\ Chinese Academy of Sciences \\ 73 East Beijing Road, Nanjing 210008, P.R.China
}

\author{
${ }^{3}$ State Key Laboratory of Soil and Sustainable Agriculture, Institute of Soil Science, Chinese \\ Academy of Sciences, Nanjing 210008, P.R. China \\ (phone: +86-25-86882169, +86-579-82291257) \\ * Corresponding author \\ e-mail: clin@niglas.ac.cn; qoliang@sina.com \\ (Received 12 $2^{\text {th }}$ Aug 2014; accepted $3^{\text {rd }}$ Sep 2014)
}

\begin{abstract}
Most previous studies are based on one year data, it is insignificant and not enough to demonstrate the correlation between land use change and water quality. Such studies have also focused on a single buffer zone, whose influence on water quality is minor compared with that of different buffer zones. According to the above-mentioned problems, we chose Meiliang Bay of Taihu Basin in China as the study area. Meiliang Bay was one of the Taihu lake divisions that faced with serious eutrophication problem, and algae blooms happened from 1987. Five buffer zones were established within 10km catchment along the lakeshore. The relationship between land use and water quality was identified with an exponential model based on 10 year data from 1995 to 2006(data of 1996, 1997 were missing). At last, we analyzed the difference among buffer zones. Finding that the effects of land use types on water quality mainly reflected in $2 \mathrm{~km}$ and $4 \mathrm{~km}$ buffer zones, and the effects of spatial patterns mainly reflected in $8 \mathrm{~km}$ buffer zone. And we also found that the critical factors had a big difference in each buffer, constructed land and farm land were always the critical factors in buffer 2 and buffer 3, but it did not always happen in other buffers. Moreover, this study could also provide practical basis for the critical lake conservation region identification and recognition.
\end{abstract}

Keywords: land use change, lake water quality, Meiliang bay, effective buffer zones, critical factors

\section{Introduction}

The rapid economic development and the accelerated urbanization in recent decades have resulted in the serious degradation of water quality in China, where the deterioration of lake water quality is a typical environmental problem. In particular, the deterioration of lake water quality in Lake Taihu Basin, as a region with a relatively developed economy and high land use intensity, is rather serious. 
A significant correlation exists between land use and water quality (Solbe, 1986; Mander et al., 1998; Su et al., 2012; Wan et al., 2014), and this correlation is influenced by land use types and their spatial patterns. Extensive research has been conducted on the relationship between land use and water quality in the watershed scale (Jun, 2011; Seeboonruang, 2012; Jun, 2013). Seeboonruang (2012) found that different land use types have different effects on water quality. Basnyat (1999) and Wang (2001) found that industrial land and agricultural land decrease water environment quality and forest land and grassland have a negative influence on water pollutant concentration. Silva and Williams (2001) found that urban area and residential land have larger influence on water chemistry than other land classes. Conversely, Tong and Chen (2002) found that forest land contains lower inorganic ions and plays an important role in relieving the degradation of water quality. Silva and Williams (2001) found that farm land greatly influences the concentrations of $\mathrm{NO}^{3-}$ and $\mathrm{SO}_{4}^{2-}$.

In the watershed scale, considerable research has confirmed the correlation between land use and water quality (Hanratty and Stefan, 1998; Brezonik and Stadelmann, 2002), but a controversy exists on the effect of land use on water quality in different buffers. Jun and Xia (2008) considered that a significant difference exists on the relationship between land use and water quality among different buffers. They found that Farm Land significantly, negatively influences the specific conductance (SC) concentration in the watershed scale but significantly, positively affects the SC concentration in $200 \mathrm{~m}$ buffer. Sawyer (2004) found that the land use in 30m buffer has larger influence on water quality than the whole watershed for it has better correlation between the buffer and water biological community structure change. However, Hunsaker and Levine (1995) found that the correlation between land use and water quality in the watershed scale is stronger than in $200 \mathrm{~m}$ or $400 \mathrm{~m}$ buffer. Similarly, Silva and Williams (2001) showed that the effect of land use change on water quality in the watershed scale is stronger than in $100 \mathrm{~m}$ buffer. By contrast, Xiang (1995) found that land use has a significant influence on water quality only in $8 \mathrm{~m}$ to $175 \mathrm{~m}$ buffer.

These inconsistent conclusions are attributed to various reasons. First, land use pattern is of great difference in various research regions. Second, the use of different water quality indices may contribute to diverse results. Nevertheless, studies have agreed that the effect of land use on water quality varies in different buffers (Hanratty and Stefan, 1998; Amiri et al., 2009; Guo et al., 2010; Jun, 2011). Numerous previous studies, however, have used a single buffer as the research region, making no in-depth comparative analysis of the effect of land use on water quality in different buffers. Many studies are also based on one year data, but the land use change in a year is insignificant and is not enough to illustrate the relationship between land use change and water quality (Hanratty and Stefan, 1998; Sawyer et al., 2004; Guo, 2010). To solve these problems, the current article is based on multiple buffers and multiple time series data of land use. Furthermore, we use a stepwise regression model to show the correlation between land use and water quality in different buffer zones.

Our objectives are (1) to identify the critical factors in different buffer zones and (2) to determine the differences among buffer zones on land use change and water quality. 


\section{Materials and Methods}

\section{Study Area}

Taihu Basin is a region with the most concentrated population, the most developed economy, the most intensive industry, and a high urbanization level in China. Algal bloom has occurred frequently in this area, particularly in Lake Meiliang (Ma, 2008), in recent years. The degradation of Lake Taihu water quality is rather serious. The algal bloom outbreak in Lake Meiliang in 2007 led to water crisis that affected more than 200 people in Wuxi, caused great economic losses, and generated extensive concern from society.

Given that $10 \mathrm{~km}$ area of Meiliang lakeshore is located in Lake Taihu Basin, we chose this lakeshore as the study area to compare the land use effects on water quality among different distances (Figure 1.). The study area was divided into five buffers, namely, $2 \mathrm{~km}$ (buffer1), 4km (buffer 2), 6km (buffer 3), 8km (buffer 4), and 10km (buffer 5).

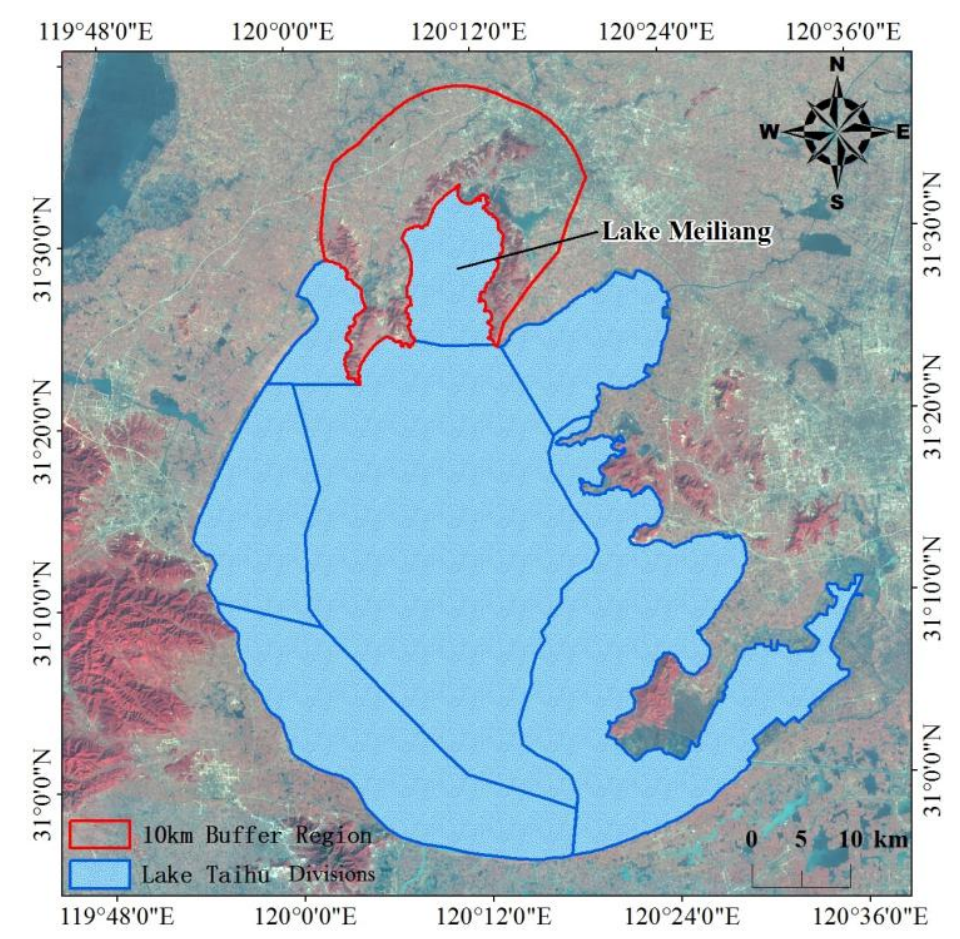

Figure 1. Location of study area. Lake Taihu can be divided into 7 parts according to Taihu Basin authority. Lake Meiliang is a part of Lake Taihu and is located on the north of Lake Taihu

\section{Land Use Classification}

Land use data were extracted through a 30m TM image by object-oriented method interpretation. The data were from 1995 to 2006 (1996 and 1997 data are missing). Owing to the low resolution of the TM image, and considering that automatic interpretation results will have a large error, we modified the interpreted results for many times after 
mining points in the field. The modified classification system employed the following six general categories: original forest (OF), artificial forest (AF), constructed land (CL), Farm Land (FL), wetland (WL), and other land (OL). OF includes evergreen broad-leaved forest, deciduous broad-leaved forest, and evergreen coniferous forest; AF includes tree garden, shrubs, garden land and planted economic forests, green belts, etc.; FL includes paddy field and dry land; CL includes residence, quarry, industrial land, traffic land, and commercial land; WL includes reservoir/pits, lakes, rivers, canals, and channels; OL includes grassland and bare land.

Land use change includes the change of land use types and spatial patterns. Area percentage was used to characterize the change of land use type, and landscape indices were used to characterize the change of spatial pattern. Fragsats 3.0 software was used to extract the representative indicators, Shannon diversity index (SHDI), Shannon evenness index (SHEI), and fractal dimension (FRACT). SHDI reflects the landscape heterogeneity, is especially sensitive to the unbalanced distribution of various patches, and reflects the complexity and variability of all kinds of patches. SHEI reflects the homogeneous degree of landscape component distribution. FRACT is a measure of complex shape irregularity.

\section{Determination of Water Quality Indicators}

The main land use types are CL, FL, and WL, and the main components of the land runoff pollutants included total nitrogen (TN), total phosphorus (TP), NH_3-N, and dissolved oxygen (DO) (Basnyat et al., 2000; Bhaduri et al., 2000). The monthly average monitoring data used were from the Taihu Basin authority. Five monitoring stations locate in Lake Meiliang (Figure 2.). The data on water quality were scattered points, and the average value was acquired. We selected five water quality indicators, namely, TN, TP, NH_3-N, DO, and chemical oxygen demand (COD).

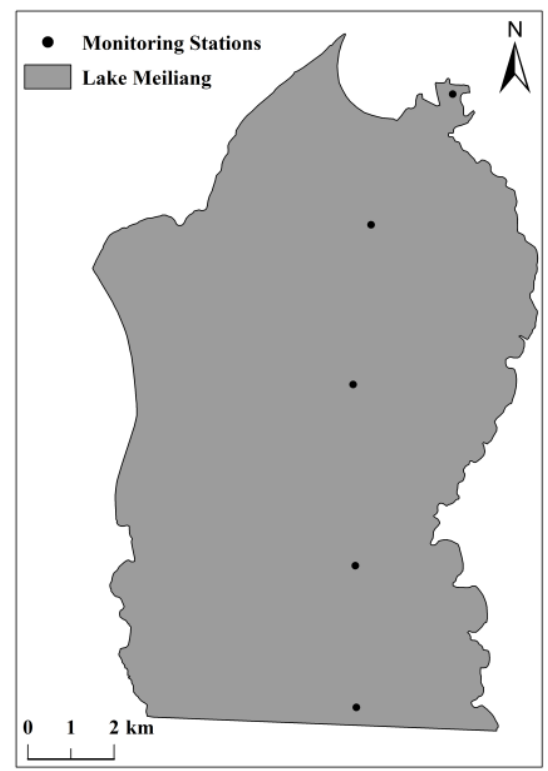

Figure 2. Distribution of monitoring stations in Lake Meiliang 


\section{Building a Correlated Model of Land Use and Water Quality}

The land use indicators included six land use types, i.e., the area proportions of Original Forest, Artificial Forest, Constructed Land, Wet Land, Farm Land, and Other Land, and three landscape parameters, namely, SHDI, SHEI, and FRACT. Considering that the exponential model can accurately represent the effect of land use pattern on water quality (Basnyat et al., 2000), we also use this model to build the relationship between land use and water quality. The expression is as follows:

$$
W Q I_{i}=a \times \exp \left(b_{1} * O F_{i}+b_{2} * A F_{i}+b_{3} * F L_{i}+\cdots+b_{9 *} S H E I_{i}\right)
$$

Where $\mathrm{a}$ is constant, and $\mathrm{b} 1, \ldots, \mathrm{b} 9$ are the coefficients that depict the direction and strength of the relationship between land use indicators and $\mathrm{WQI}_{\mathrm{i}}$. When the value of $\mathrm{b}$ is negative, this land use type or landscape index has a negative effect on water quality. When the value of $b$ is positive, this land use type or landscape index has a positive effect on water quality. We modeled the relationship between land use and water quality in each buffer using the stepwise regression method. The correlation coefficient $\left(\mathrm{R}^{2}\right)$ was used to compare the correlation between land use and water quality in different buffer zones.

\section{Results}

\section{Land Use Characteristic}

Six land use types were classified in this study. The classification results of land use in five buffer zones from 1995 to 2006 along the lakeshore were generated. However, only the results of land use classification in 1995, 2000, and 2006 are listed (Figure 3.).

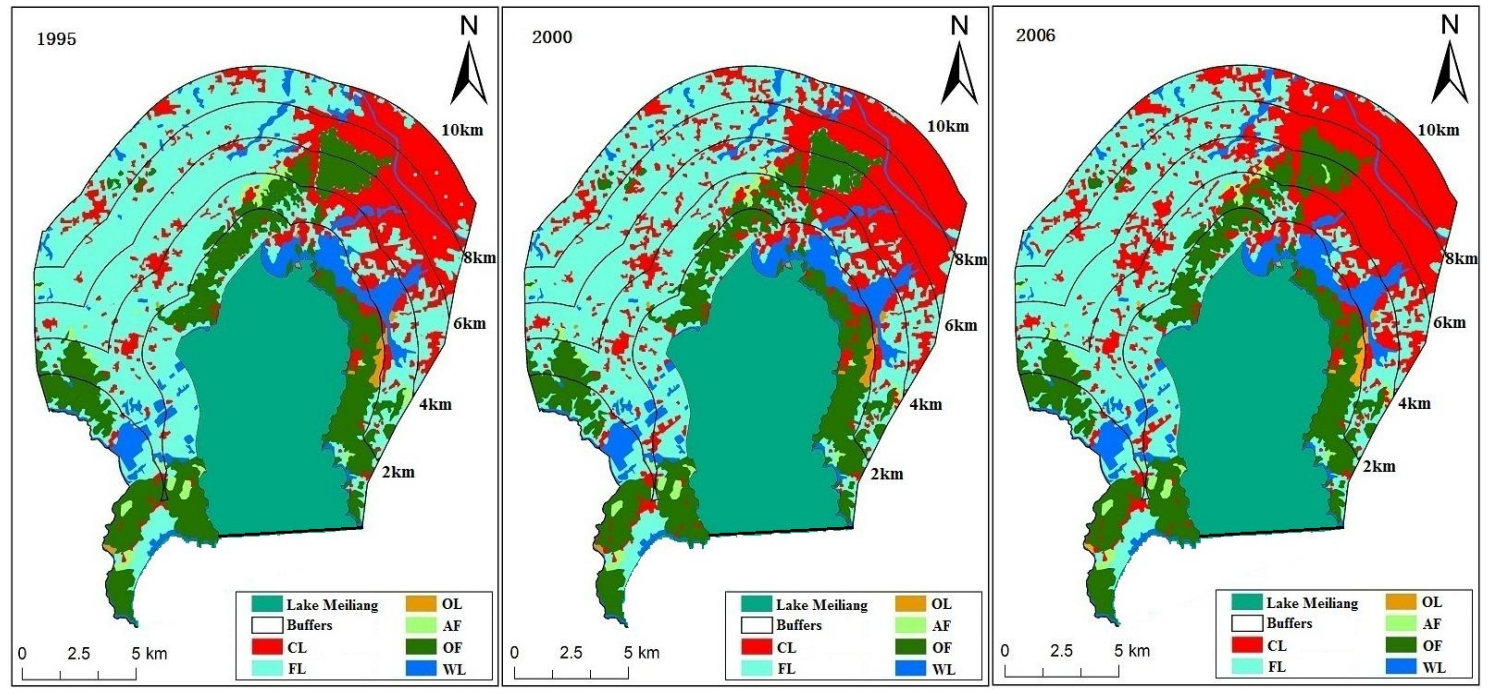

Figure 3. Results of land use classification in 1995, 2000, and 2006 
The land use change from 1995 to 2006 mainly embodied in the following three land use types: (1) the area of CL had increased rapidly, especially in the north of Lake Meiliang from 1995 to 2000; (2) the area of FL decreased fast in the northwest of the study area and was fragile; (3) OF was increasingly fragile, especially in the west of Lake Meiliang. The land use change was analyzed in details on two sides, namely, the change of proportions of land use types and the landscape index in different buffer zones.

With the increase of buffer distance, the change of the proportion of land use type was manifested in two main classes, namely, Constructed Land and Farm Land. However, Farm Land changed mainly because of Constructed Land; thus, we selected only Constructed Land for analysis. From Figure 4 we can see that, Constructed Land expanded in each buffer, but a significant difference was found in various buffers, as well as in different years. For example, a proportion of CL increased by $13.27 \%$ in buffers 1 to 4 but decreased by $9.16 \%$ in buffers 4 and 5 (Figure 4). The proportion of Constructed Land had an irregular fluctuation in 1995 and 2000 but had a significant upward trend in 2006.

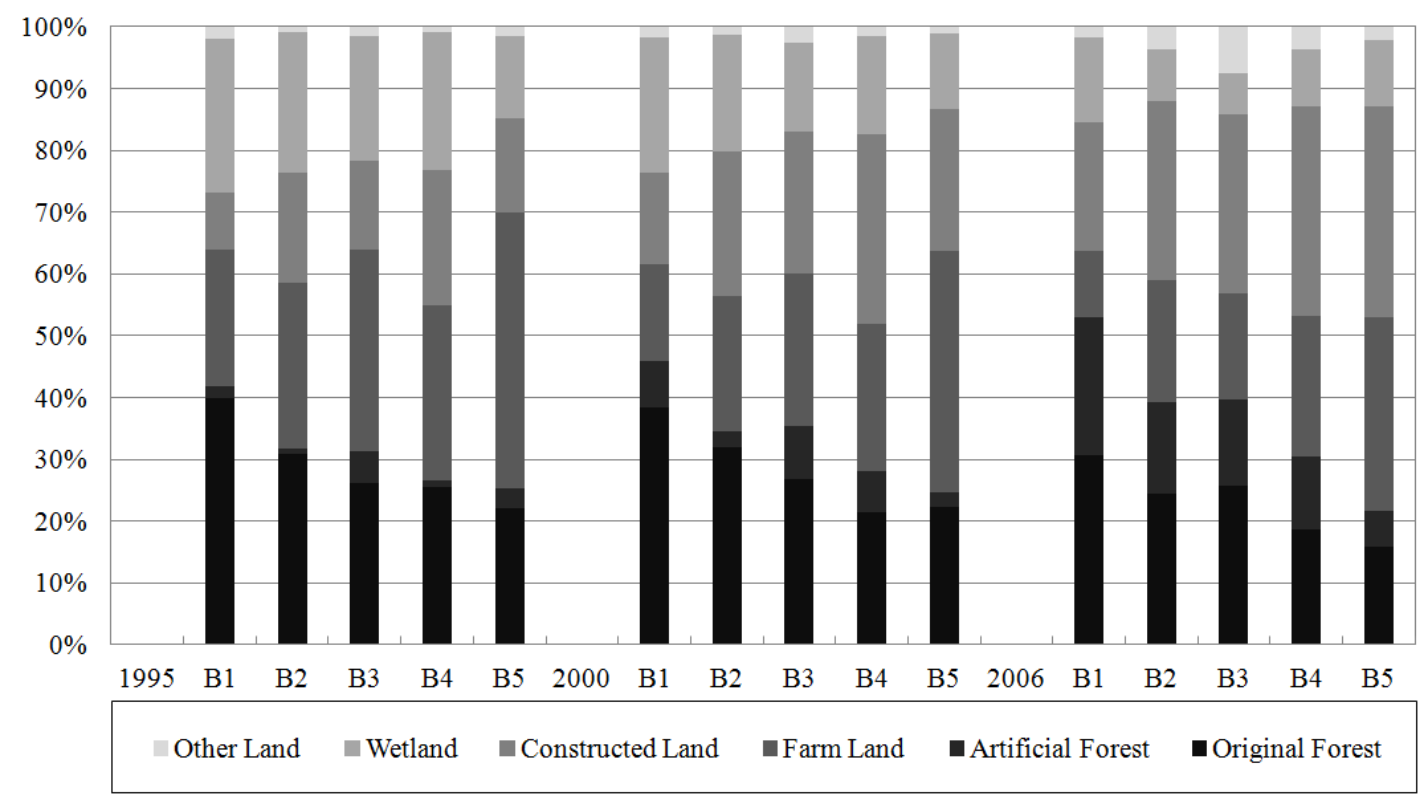

Figure 4. Land use proportions in five buffer zones in 1995, 2000 and 2006. Land use proportions varied with increasing size of the buffer zone

As the change of time, FRACT value indicated a gradually upward trend in buffers 1 and 2 and an irregular fluctuation in buffers 3 to 5 (Figure 5(a)). FRACT values in buffers 4 and 5 were higher than other buffers. The minimum value distribution differed with time. For example, the minimum value in buffer 1 was about 1.15 , but it was 1.42 in buffer 3 and 1.3 in buffer 2. The symbols of SHDI in all buffers were two "V"-shaped curves (Figure 5(b)). For example, the minimum value appeared in buffers 1, 2, and 4 in 2003, but it appeared in buffer 3 in 2005 and buffer 5 in 2004. Compared with the other 
two landscape indices, the change of SHEI was more complex (Figure 5(c)). Except for buffers 2 and 3, we found a significant fluctuation in the curves of SHEI in other buffers.

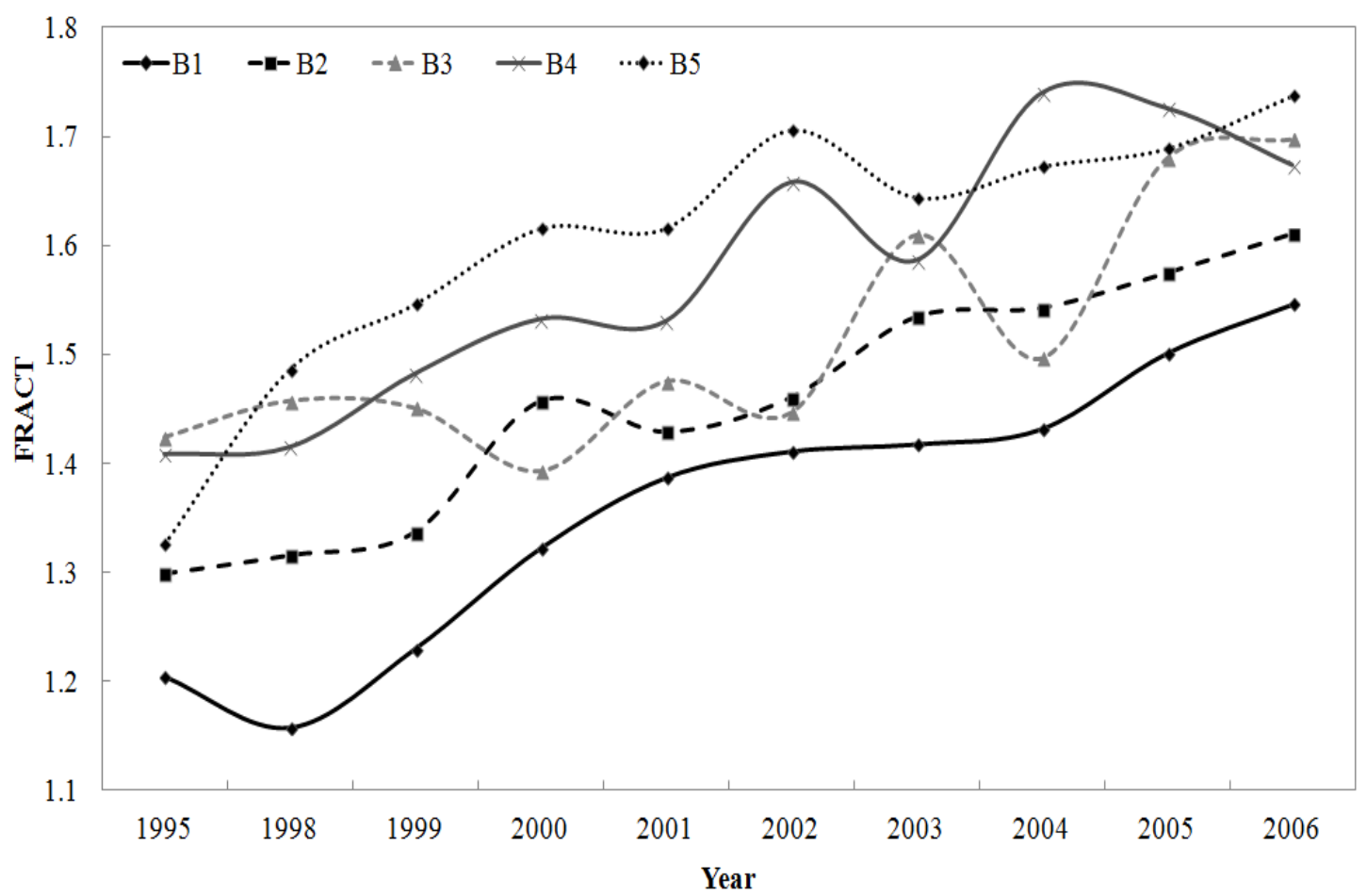

(a)

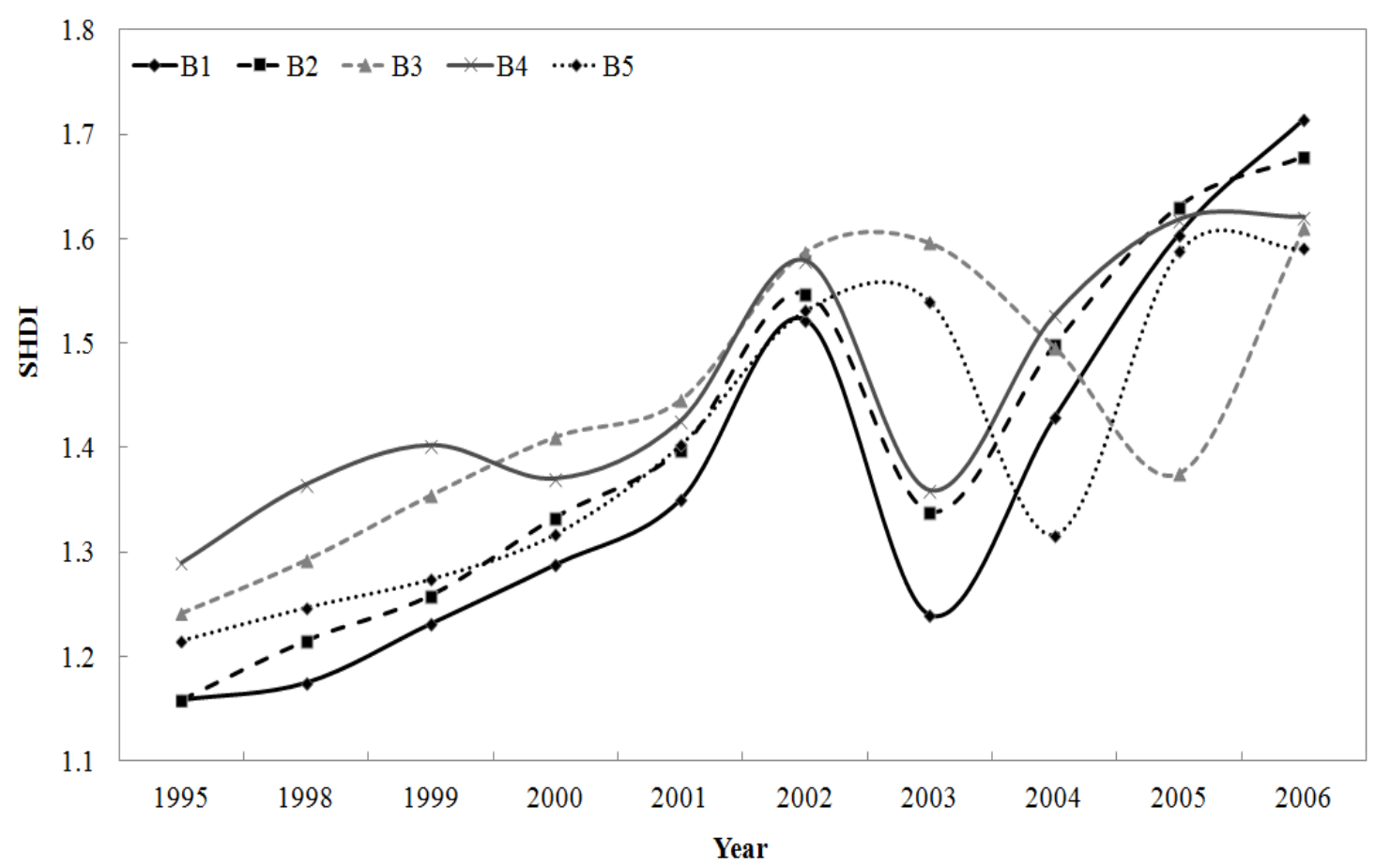

(b) 


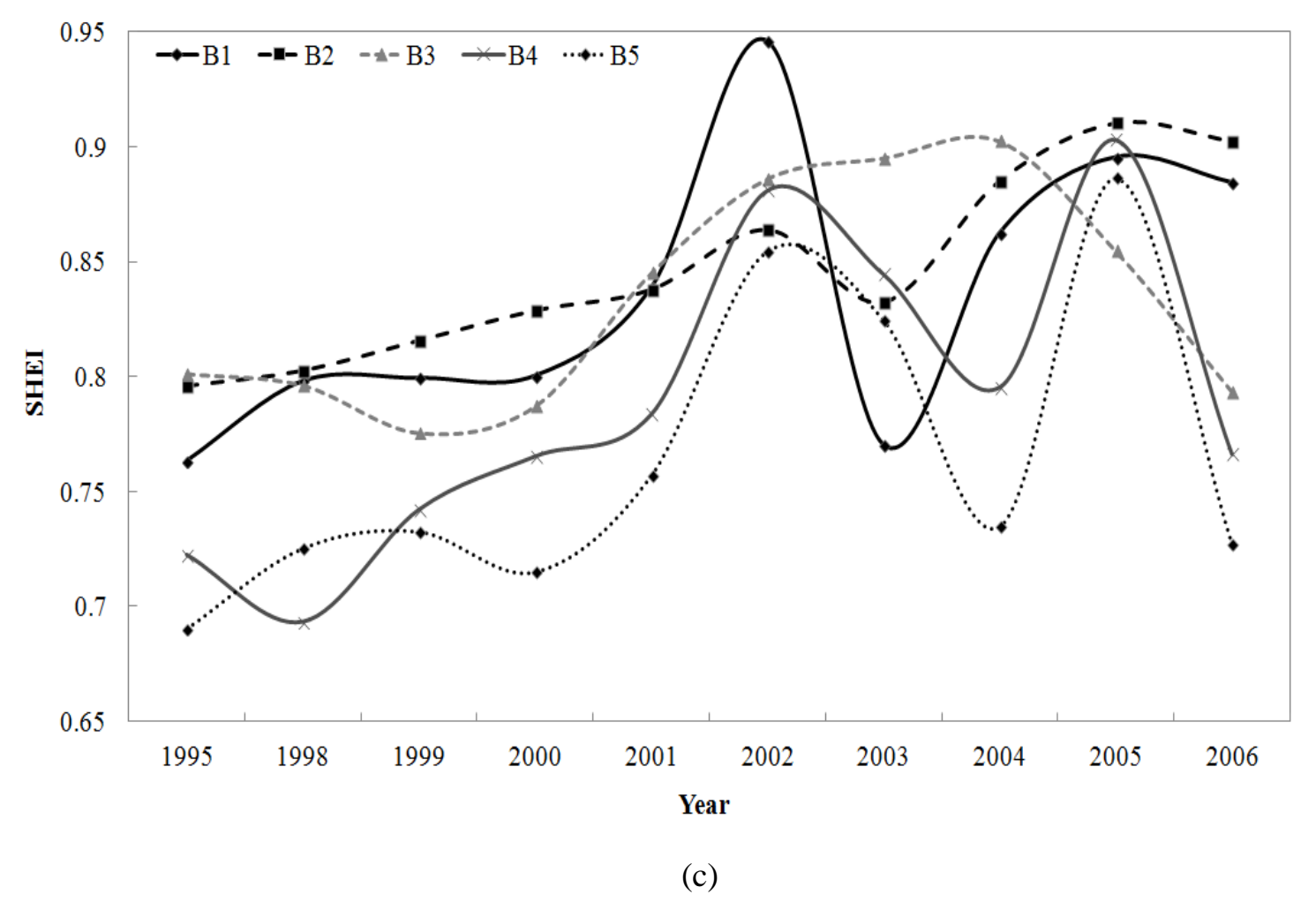

Figure 5. Typical trends of landscape indices with the change of time in five buffer zones.

Figure 5(a) is the curve of FRACT, Figure 5(b) is the curve of SHDI and Figure 5(c) is the curve of SHEI

\section{Change of Water Quality}

In this article, we chose five indicators (Figure 6) to analyze the change of water quality in Lake Meiliang. The levels of TN, TP, COD, NH_3-N, and DO were over the national grade V (according to GB3838-2002 by EPA of China, 2002), and the degradation of water quality was serious (Figure $6(a)$ ). The variability of these parameters in different years was remarkable. For example, the change of COD concentration values was very small from 1998 to 2002 but had a regular fluctuation from 2002 to 2006. The NH_3-N concentration values sharply dropped from 1995 to 1998 and returned to their peak in 2004. The changing trends of DO and COD were similar, and their minimum values appeared only in 2006. The NH_3-N concentration values were maximized in 2004. The TP concentration values obviously fluctuated from 1995 to 2006, the maximum value appeared in 1999 and 2004, and the minimum value appeared in 2000 (Figure 6(b)). 


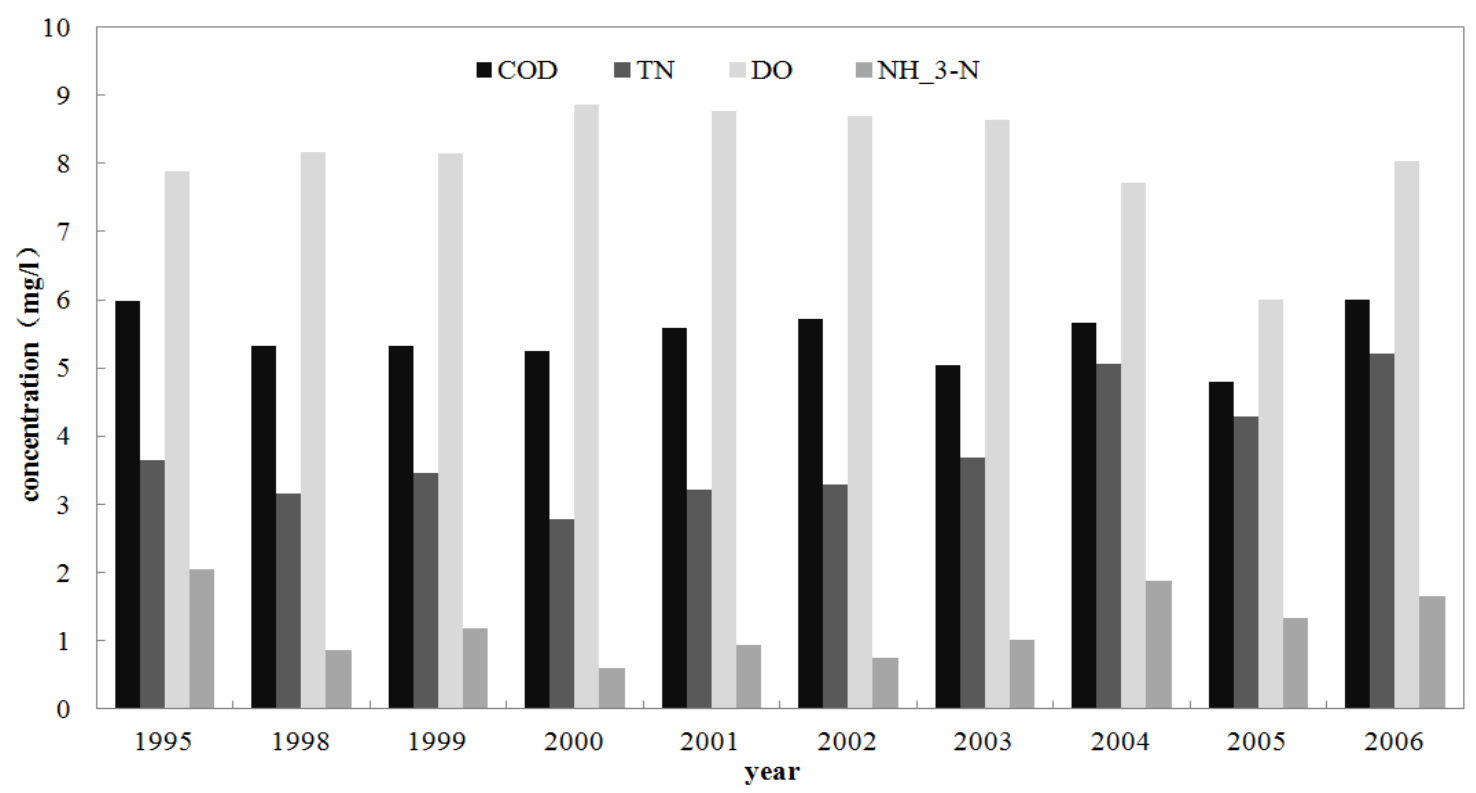

(a)

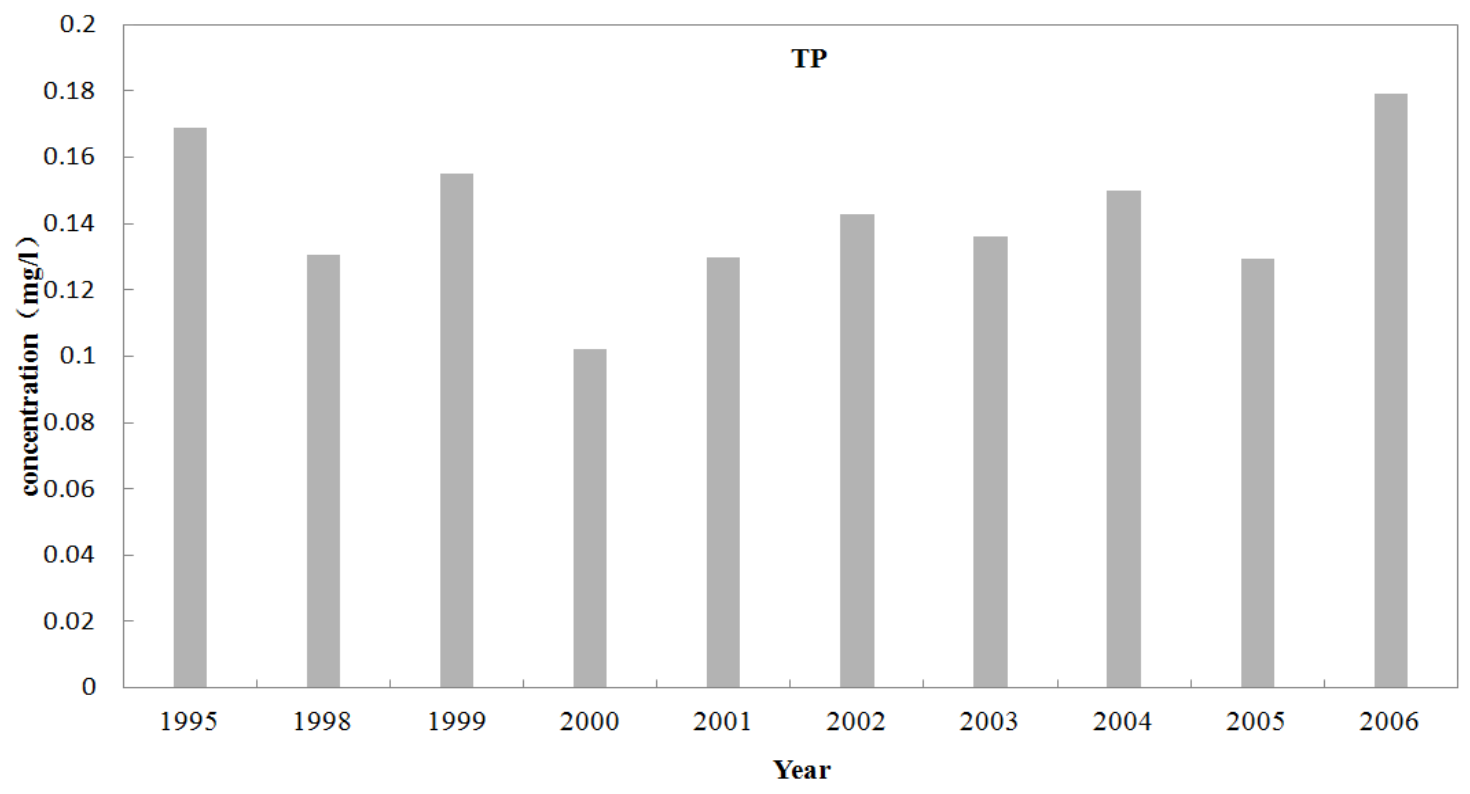

(b)

Figure 6. Changes in the surface water quality of COD, NH_3-N, DO, TN, and TP in Lake Meiliang. Figure 6(a) is the results of $\mathrm{COD}, \mathrm{NH}_{-} 3-\mathrm{N}, \mathrm{DO}$ and Figure $6(b)$ is the results of TP and $T N$

\section{Relationship between Land Use and Water Quality}

In this article, we used $\mathrm{R}^{2}$ to indicate the relationship between land use and water quality in various buffer zones (Figure 7) (Sliva, 2001). $\mathrm{R}^{2}$ of COD decreased from buffers 1 to 5, that of NH_3-N decreased in buffers 1 and 2 but increased in buffers 3 to 5, 
that of DO was similar in buffers 1 and 2 and in buffers 4 and 5, that of TN appeared a minimum value in buffer 3 , and that of TP appeared a maximum value in buffer 3 .

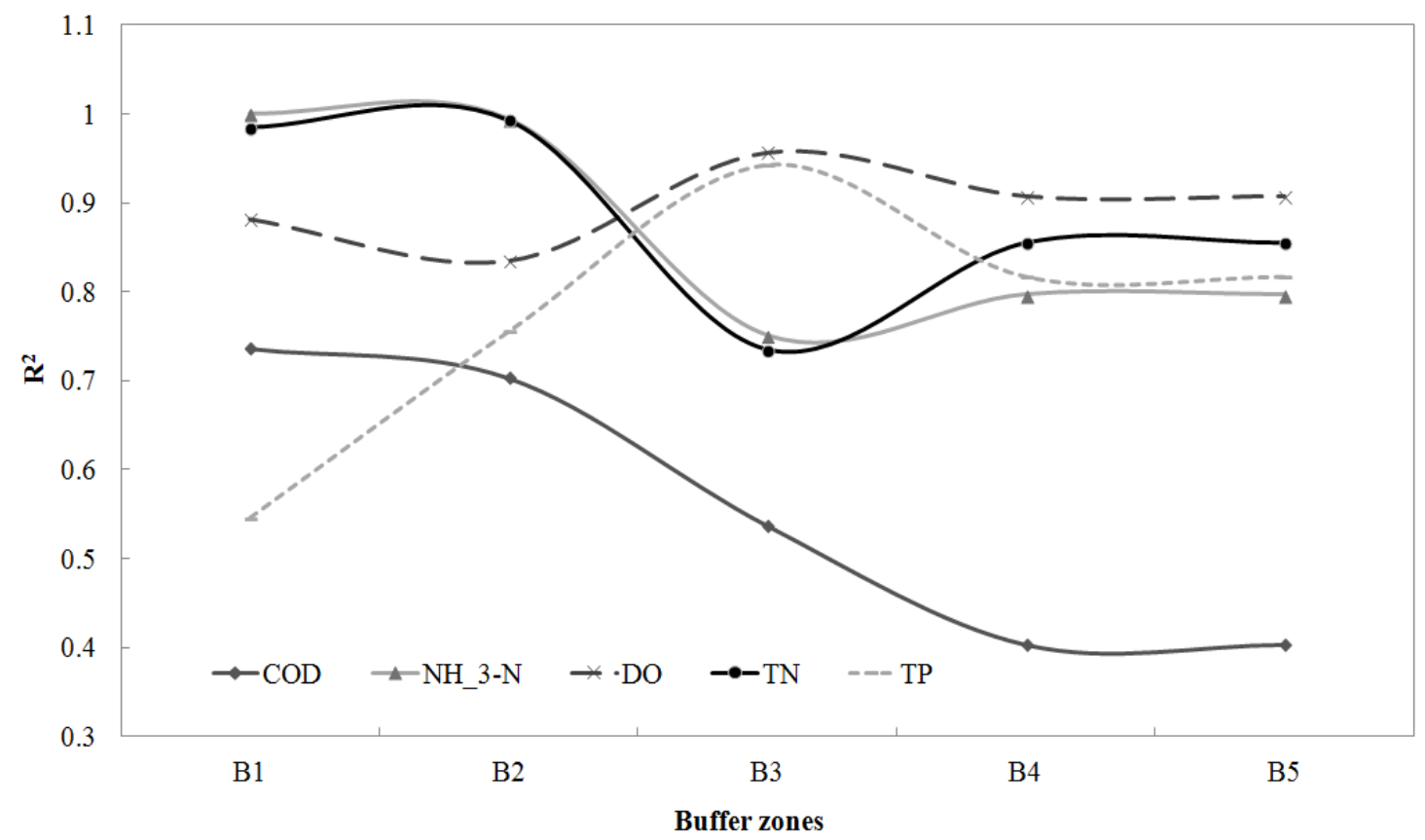

Figure 7. $R^{2}$ curves appearing in the multiple regression model from buffers 1 to 5

Regarding the correlation between the specific factors of land use and water quality, this study considered TN as an example. The land use factors that had a significant effect on water quality differed in various buffer zones (Table 1). Original Forest, Artificial Forest, Constructed Land, and Wet Land had a significant correlation with TN in buffer 1, but only Constructed Land and Wet Land had a significant correlation with TN in buffer 2. Farm Land and the SHDI of spatial pattern had a significant effect on $\mathrm{TN}$. The correlation between land use types and TN decreased in buffer 4 , where only Wet Land, Original Land, and FRACT had a significant correlation with TN. Buffer 5 was almost similar to buffer 4, where Farm Land had a significant effect on TN.

Table 1. Results of multiple stepwise regression of land use change and lake water quality from buffer 1 to buffer 5 (Results are significant at $p<0.05$ ). The change of land use type and landscape index has a positive (expressed as a "+") and negative (expressed as a "-") effect on lake water quality.

\begin{tabular}{|c|c|c|c|c|c|c|c|c|c|c|c|c|c|}
\hline \multirow{2}{*}{ Buffers } & \multirow{2}{*}{ Indicators } & \multicolumn{6}{|c|}{ Land Use Indicators } & \multicolumn{3}{|c|}{ Landscape Indicators } & \multirow[b]{2}{*}{$\mathrm{R}$} & \multirow[b]{2}{*}{$\mathrm{R}^{2}$} & \multirow[b]{2}{*}{$P$} \\
\hline & & OF & $\mathrm{AF}$ & FL & $\mathrm{CL}$ & WL & $\mathrm{OL}$ & FRACT & SHDI & SHEI & & & \\
\hline \multirow{4}{*}{ B1 } & COD & + & & - & & & + & & & & 0.858 & 0.736 & 0.002 \\
\hline & $\mathrm{PH}$ & & - & - & - & & & & & & 0.976 & 0.952 & $<0.001$ \\
\hline & NH_3-N & & + & & - & + & & & & & 1.000 & 1.000 & $<0.001$ \\
\hline & DO & - & - & + & & & & & & & 0.939 & 0.882 & $<0.001$ \\
\hline
\end{tabular}




\begin{tabular}{|c|c|c|c|c|c|c|c|c|c|c|c|}
\hline & $\mathrm{TN}$ & & + & & + & & + & & 0.993 & 0.985 & $<0.001$ \\
\hline & TP & & + & + & + & & & & 0.738 & 0.545 & 0.006 \\
\hline \multirow{6}{*}{ B2 } & COD & & + & & - & - & & & 0.838 & 0.703 & 0.001 \\
\hline & PH & & + & & + & + & & & 0.984 & 0.963 & $<0.001$ \\
\hline & NH_3-N & + & & - & - & & & & 0.997 & 0.994 & $<0.001$ \\
\hline & DO & & + & & & + & & + & 0.914 & 0.835 & $<0.001$ \\
\hline & $\mathrm{TN}$ & - & & & + & & & + & 0.681 & 0.463 & 0.015 \\
\hline & TP & - & + & & & & - & & 0.869 & 0.755 & 0.010 \\
\hline
\end{tabular}

Table 1. (continued)

\begin{tabular}{|c|c|c|c|c|c|c|c|c|c|c|c|c|c|}
\hline \multirow{2}{*}{ Buffers } & \multirow{2}{*}{ Indicators } & \multicolumn{6}{|c|}{ Land Use Indicators } & \multicolumn{4}{|c|}{ Landscape Indicators } & \multirow[b]{2}{*}{$\mathrm{R}^{2}$} & \multirow[b]{2}{*}{$\mathrm{P}$} \\
\hline & & $\mathrm{OF}$ & $\mathrm{AF}$ & FL & $\mathrm{CL}$ & WL & $\mathrm{OL}$ & FRACT & SHDI & SHEI & $\mathrm{R}$ & & \\
\hline \multirow{6}{*}{ B3 } & $\mathrm{COD}$ & - & & & - & & & + & & & 0.733 & 0.537 & 0.03 \\
\hline & $\mathrm{PH}$ & & & & & + & & + & + & & 0.732 & 0.536 & 0.031 \\
\hline & NH_3-N & - & & & & - & & & - & & 0.867 & 0.751 & 0.002 \\
\hline & DO & & & & & & - & - & - & & 0.978 & 0.957 & $<0.001$ \\
\hline & $\mathrm{TN}$ & - & & & & - & & & - & & 0.857 & 0.735 & 0.001 \\
\hline & TP & & & & & & - & - & - & & 0.971 & 0.943 & $<0.001$ \\
\hline \multirow{6}{*}{ B4 } & $\mathrm{COD}$ & & & & & & - & & + & - & 0.685 & 0.403 & 0.018 \\
\hline & $\mathrm{PH}$ & & & & + & + & - & & & & 0.802 & 0.643 & 0.002 \\
\hline & NH_3-N & & & & + & + & - & & & & 0.893 & 0.797 & 0.012 \\
\hline & DO & & & & - & - & + & & & & 0.953 & 0.908 & 0.002 \\
\hline & $\mathrm{TN}$ & & & & & - & + & - & & & 0.925 & 0.855 & 0.001 \\
\hline & TP & & & & & & - & + & & + & 0.904 & 0.817 & 0.002 \\
\hline \multirow{6}{*}{ B5 } & COD & & & & & & - & & + & - & 0.635 & 0.403 & 0.018 \\
\hline & $\mathrm{PH}$ & & & & + & + & - & & & & 0.802 & 0.643 & 0.002 \\
\hline & NH_3-N & & & & - & - & + & & & & 0.893 & 0.797 & 0.012 \\
\hline & DO & & & & - & - & + & & & & 0.953 & 0.908 & $<0.001$ \\
\hline & $\mathrm{TN}$ & & & & & - & + & - & & & 0.925 & 0.855 & 0.001 \\
\hline & $\mathbf{T P}$ & & & & & & - & + & & + & 0.904 & 0.817 & $<0.001$ \\
\hline
\end{tabular}

\section{Discussions}

\section{Critical Factors in Each Buffer}

The critical factors in each buffer are the land use indicators that significantly affect water quality. Land use has a positive (expressed as a "+") and negative (expressed as a "-") effect on water quality. With the increase of buffer zones, the critical factors vary.

Critical factors have two kinds, namely, land use types and landscape indices. Land use type had a significant effect on water quality in buffer 1, where Wet Land, Farm Land, and Original Forest were the critical factors (Table 1). Figure 3 indicates that Original Forest was 
the main land use type in buffer 1 and could have cushion for pollutants. The main class of Wet Land in buffer 1 was water. This land use type is located in the east of Wuxi and directly connected to Lake Meiliang. The pollutants could easily flow into the lake through water, and Original Forest hardly controlled them. Except for TN and TP, other water quality indicators were affected by the land use types on both positive and negative sides.

Wet Land, Farm Land, and Constructed Land were the critical factors in buffer 2. Wet Land had a significant, negative effect on the water quality indicators in buffer 2, such as COD, NH_3-N, and TN. Farm Land and Constructed Land had a significant, positive effect on water quality and released pollutants, whereas Wet Land diluted and adsorbed such pollutants.

Compared with buffer 2 , the effects of land use types on water quality decreased in buffer 3 and mainly acted as negative effects. Original Forest, Farm Land, and Constructed Land were the critical factors in buffer 3. Original Forest had the most significant effect on water quality and had a negative effect on COD, NH_3-N, and TN. The area of Original Forest is the largest among all the land use types and distributed along the lakeshore and could have a cushion for the pollutants from Farm Land and Constructed Land. The critical factors in buffer 4 are Constructed Land, Wet Land, and Original Land. Among them, Other Land had the most significant effect on water quality. Other Land had a negative effect on TP, COD, and NH_3-N and a positive effect on TN and DO. Buffer 5 was similar to buffer 4, where Other Land had a positive effect on NH_3-N, DO, and TN.

The critical factors of spatial patterns varied in different buffer zones. The number of critical factors increased with increasing buffer zones. For example, only one critical factor was found in buffer 1, but approximately two critical factors were found in buffers 2 to 5 (Table 1). FRACT was the only critical factor that had a significant effect on water quality in buffer 1. SHEI and FRACT had a critical effect on water quality in buffer 2, and the critical factors in buffers 3 to 5 were FRACT, SHDI, and SHEI. The reason for this result was that more land use types exist in buffers 3 to 5 than in buffers 1 and 2 (Figure 3). Farm Land and Constructed Land were the main land use types in buffers 3 to 5, and the land use change mainly reflected on Farm Land and Constructed Land. The change of land use would result in the change of spatial patterns, which would cause water quality degradation indirectly.

\section{Comparison among Different Buffers on the Effect of Land Use on Water Quality}

This study found that Farm Land had a significant, positive effect on COD and TN and that Constructed Land had a significant, positive effect on NH_3-N and DO at the watershed scale (Table 1). Sonzogni (1980) showed that the concentrations of COD, TP, and TN from intensive agriculture and urban areas were normally 10 times to 100 times greater than those from forested and idle lands; the pollutants from these land use types would constantly flow into the lake, which would result in the degradation of water quality. Bannerman et al. (1993) and Tong and Chen (2002) found that Constructed Land areas, including commercial, industrial, street, and high-density residential land, were the main pollutant sources. Similarly, Guo (2010) showed that the proportions of rural habitation and commercial land use had a positive correlation with TN, TP, NH_3-N, COD, and Se. Our results also indicated that Wet Land had a negative effect on NH_3-N, TN, and Dissolved Oxygen. Original Forest 
had a negative effect on NH_3-N and TP, which could be due to the function of the classes in Wet Land and Original Forest that absorbed or retained the pollutants.

With the change of buffer zones, the correlation between land use and water quality varies. Original Forest had a significant, positive effect on COD in buffer 1, but this effect was not found in buffers 2 to 5 (Table 1). Original Forest had both positive and negative effects on the water quality indicators in buffers 1 and 2, but it only had a negative effect in buffers 3 to 5. Original Forest had a significant, negative effect on COD, NH_3-N, and TN in buffer 3. Farm Land had a positive correlation with Dissolved Oxygen in buffers 1 and 2, but this correlation did not exist in buffers 3 to 5. Constructed Land had a positive influence on NH_3-N, TN, and TP in buffer 1, but it had a significant effect on no more than two water quality indicators in the other buffer zones.

We used only one water quality indicator to analyze the difference of the effects of land use types on water quality among buffer zones. As $\mathrm{TN}$ is an important indicator that can significantly affect the degradation of water quality, we used TN to analyze the change on the relationship between land use and water quality. As shown in Table 1, TN was only significantly affected by Constructed Land in buffers 1 and 2, by Farm Land in buffer 3, and by Wet Land in all buffers.

The land use classification results (Figure 3) indicate that Original Forest, Wet Land, and Farm Land are the main land use types in buffer 1. Given Original Forest is distributed along the lakeshore and had a negative effect on water quality, this land use type could act as a buffer zone of pollutants and help protect the water quality of Lake Taihu. Farm Land, Constructed Land, Wet Land, and Original Forest exist in buffer 2, of which Farm Land and Original Forest are the main classes. As Farm Land had a significant, positive effect on water quality, the pollutants from Farm Land could flow into lake when farming activity is frequent and the use of fertilizer is unreasonable. The main land use types in buffers 3, 4, and 5 are Constructed Land, Farm Land, and Original Forest, of which the first two classes mainly had a positive effect on water quality. Although Farm Land had larger area than other classes, Constructed Land could produce a large amount of pollutants and had such a great influence on water quality as Farm Land.

Spatial patterns also affect water quality. They had an insignificant effect on water quality in buffers 1 and 2. Only FRACT had a significant, negative effect on TN. This finding might be related to the restriction of land use by the local government along the lakeshore. However, the effect of spatial pattern on water quality reached peak in buffer 3, and SHDI was the landscape index that had the most significant effect on water quality. With the diversity of land use in buffer 3, and given that this buffer zone is located in the water source protection zone set by the local government, the indicator of spatial pattern mainly had a negative effect on water quality. SHDI, FRACT, and SHEI were the critical factors in buffers 4 and 5. SHDI had a significant, positive effect on COD, and SHEI and FRACT significantly affected TP. The reason for such effects was that the proportion of Farm Land and Constructed Land increased, as well as the amount of pollutants. The land use intensity was also high and could play an important role in enhancing the effect of spatial pattern. 
Overall, the effect of land use type on water quality mainly reflected in buffers 1 and 2, and the effect of spatial pattern mainly reflected in buffers 3 to 5 .

\section{Conclusions}

In this study, we model the relationship between multi-temporal land use data and the corresponding water quality within $10 \mathrm{~km}$ land area to explore the effect of land use change on the water quality of Lake Meiliang. The $10 \mathrm{~km}$ land scope was divided into five buffer zones. We studied the differences of the effect of land use change on water quality among different buffer zones and identified the critical factors in each buffer zone.

This study indicated that land use types and spatial patterns greatly affect water quality and that a significant difference exists in different buffer zones. The effects of land use types on water quality mainly reflected in buffers 1 and 2 , and the effects of spatial patterns mainly reflected in buffers 4 and 5. We found that (1) the proportions of Farm Land and Original Forest were the critical factors in buffers 1 to 3, (2) the proportion of Wet Land was the critical factor in buffers 1, 2, 4, and 5, (3) the proportion of CL was the critical factor in buffers 2 to 5, (4) the effect of spatial pattern reached peak in buffer 3, and SHDI, SHEI, and FRACT were the critical factors in buffers 3 to 5. Our study indicated that the identification of the effective buffer zones could provide new information and ideas for planning and management.

Acknowledgment. This work was funded by the National Natural Science Foundation of China (41301227) and the research fund of State Key Laboratory of Soil and Sustainable Agriculture, Nanjing Institute of Soil Science, Chinese Academy of Science (Y412201427). And the data source was supported by Scientific Data Sharing Platform for Lake and Watershed.

\section{REFERENCES}

[1] Amiri, B.J., Nakane, K. (2009): Modeling the linkage between river water quality and landscape metrics in the Chugoku District of Japan. - Water Resource Management 23: 931-956.

[2] Basnyat, P., Teeter, L.D., Lockaby, B. G., Flynn, K.M. (2000): The use of remote sensing and GIS in watershed level analyses of non-point source pollution problems. - Forest Ecology Management 128: 65-73.

[3] Basnyat, P., Teeter, L.D., Flynn, K.M., Lockaby, B.G.(1999): Relationships between landscape characteristics and nonpoint source pollution inputs to Coastal Estuaries. Environmental Management 23: 539 - 549.

[4] Bannerman, R.T., Owens, D.W., Dodds, R.B., Hornewer, N.J. (1993): Source of pollutants in Wisconsin stormwater. - Water Science and Technology 28: 241-259.

[5] Brezonik, P.L., Stadelmann, T.H. (2002): Analysis and predictive models of stormwater runoff volumes,loads, and pollutant concentrations from watersheds in the Twin Cities metropolitan area, Minnesota, USA. - Water Resources 36: 1743-1757.

[6] Guo, Q.H., Ma, K.M., Liu, Y., Kate, H. (2010): Testing a Dynamic Complex Hypothesis in the Analysis of Land Use Impact on Lake Water Quality. - Water Resource Management 24: 1313-1332. 
[7] Hanratty, M.P., Stefan, H.G. (1998): Simulating climate change effects in a Minnesota agricultural watershed. - Journal of Environmental Quality 27: 1524-1532.

[8] Hunsaker, C.T., Levine, D.A. (1995): Hierarchical approaches to the study of water quality in rivers. - Bioscience 45:193-202.

[9] Jun, T., Xia, Z.G. (2008): Examining spatially varying relationships between land use and water quality using geographically weighted regression I: Model design and evaluation. Science of Total Environment 407: 358-378.

[10] Jun, T. (2011): Spatially varying relationships between land use and water quality across an urbanization gradient explored by geographically weighted regression. - Applied geography 31: 376-392.

[11] Jun, T. (2013): Spatial Variations in the Relationships between Land Use and Water Quality across an Urbanization Gradient in the Watersheds of Northern Georgia, USA. Environmental Management 51: 1-17.

[12] Ma, R.H., Kong, F.X., Duan, H.T., Zhang, S.X., Kong, W.J., Hao, J.Y. (2008): Spatio-temporal distribution of cyanobacteria blooms based on satellite imageries in Lake Taihu, China. - Journal of Lake Science 20: 687-694.

[13] Mander, U., Kull, A., Tamm, V., Kuusemets, V., Karjus, R. (1998): Impact of climatic fluctuations and land use change on runoff and nutrient losses in rural landscape. Landscape and Urban Planning 41: 229-238.

[14] Sawyer, J.A., Stewart, P.M., Mullen, M.M., Simon, T.P., Bennett, H.H. (2004): Influence of habitat, water quality, and land use on macro-invertebrate and fish assemblages of a southeastern coastal plain watershed, USA. - Aquatic Ecosystem Health and management 7: 85-99.

[15] Seeboonruang, U. (2012): A statistical assessment of the impact of land uses on surface water quality indexes. - Journal of Environmental Management 101: 134-142.

[16] Sliva, L., Williams, D.D. (2001): Buffer zone versus whole catchment approaches to studying land-use impact on river water quality. - Water Resources 35: 3462-3472.

[17] Solbe, J.F., De, L.G. (1986): Effects of Land Use on Fresh Waters: Agriculture, Forestry, Mineral Exploitation, Urbanization. Ellis Horwood Ltd., London, UK. 1-352.

[18] Sonzogni, W.C., Chesters, G., Coot, D.R. (1980): Pollution from land runoff. Environmental Science and Technology 14: 148-153.

[19] Su, S.L., Xiao, R., Zhang, Y. (2012): Multi-scale analysis of spatially varying relationships between agricultural landscape patterns and urbanization using geographically weighted regression. - Applied Geography 32: 360-375.

[20] Tong, S.T.Y., Chen, W.L. (2002): Modeling the relationship between land use and surface water quality. - Journal of Environmental Management 66: 377-393.

[21] Wang, X. (2001): Integrating water-quality management and land-use planning in a watershed context. - Journal of Environmental Management 61:25-36.

[22] Wan, R.R., Cai, S.S., Li, H.P., Yang, G.S. (2014): Inferring land use and land cover impact on stream water quality using a Bayesian hierarchical modeling approach in the Xitiaoxi River Watershed, China. - Journal of Environmental Management 133: 1-11.

[23] Xiang, W.N. (1995): GIS-based analysis: injection of geographic information into landscape planning. - Landscape and Urban Planning 34: 1-10.

\section{APPENDIX}

Electronic Appendix: Result Data 